\title{
THE FORMATION OF ECOLOGO-PEDAGOGICAL ACTIVITY SKILLS OF FUTURE BIOLOGY TEACHERS DURING THE TRAINING PROCESS
}

Skyba Mariya, candidate of pedagogic sciences, associate professor, candidate for a doctor's degree, Institute of higher education of the National academy of educational sciences of Ukraine, Bastionna strett, 9, r. 810, 01014, Kyiv, Ukraine, mary_skiba@ukr.net

The article gives the definition of the term «training» and its value for higher education system. The main point of this article is to explain the importance of interactive methods and technology for the formation process of ecologopedagogical activity skills; to demonstrate the examples of their usage during the training process of future biology teachers, especially in the course of ecologo-pedagogical disciplines.

We regard educational training as an active educational activity of students during which they do training exercises. The aim of the training exercises is to form organizational skills of ecologo-pedagogical activity under the teacher's guidance which is based on the instructive and methodical materials. These materials correspond to all modern standards of professional activity. It is given the example of a training exercise developed for a discipline «The organization of ecologo-pedagogical activity" on the topic of «Ecological values in the system of National education».

It is also highlighted the value of the training exercise to form the knowledge about national ecology and to form the application of its elements during the process of studying biology (done both on the lessons and off-hour activities). Training exercise also helps to form cognitive, communicative, organizational, and constructive skills of ecologo-educational activity. There were made conclusions that realization of ecological training exercise attracts participant's attention to the solving of environmental problems; activates nature protection activities; develops the independence of thought.

Key words: ecologo-pedagogical activity; future biology teachers; training; training exercise; training structure.

Стаття надійшла до редакції 19.05.2016

Прийнято до друку 27.10.2016

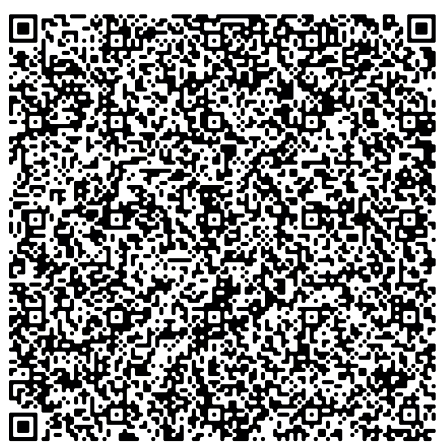

\section{РЕФЛЕКСИВНИЙ ПІДХІД ДО ФОРМУВАННЯ МЕТОДИЧНОЇ КОМПЕТЕНТНОСТІ У МАЙБУТНІХ ВИКЛАДАЧІВ ІНОЗЕМНИХ МОВ У ПРОЦЕСІ САМОСТІЙНОЇ РОБОТИ}

У статті розглянуто рефлексивний підхід як один із засадничих для організації навчального процесу з формування методичної компетентності майбутніх викладачів іноземних мов під час їхної самостійної роботи. Окреслено особливості реалізації рефлексивного підходу шляхом відповідної організації освітнього процесу, спрямованого на формування й розвиток у магістрантів рефлексивного знання, рефлексивного мислення, рефлексивної позииї, рефлексивних умінь, методичної рефлексії.

Ключові слова: інформачійно-комунікачійне навчальне середовище; магістрант; майбутній викладач іноземних мов; методична компетентність; методична рефлексія; рефлексивний підхід; самостійна робота.

Вступ. В умовах сьогодення науковці все більше уваги приділяють не лише пошуку нових форм, способів і засобів оптимізації методичної підготовки майбутнього вчителя / викладача іноземних мов (далі IM), але й упровадженню но- вих підходів, які визначають стратегію навчання та вибір методу навчання, який реалізує таку стратегію (Азимов Э. Г., 2009, с. 200). Серед таких, наприклад, інтегративно-рефлексивний (Соловова Е. Н., 2004), інтегративний (Ходыкина А. В., 
2011). У процесі загальної професійної підготовки майбутнього вчителя IM науковці пропонують використовувати контекстний (Семенова Е. С., 2007), компетентнісний (Курникова Н. С., 2008) підходи. Завданням сучасної професійної освіти є не лише підготовка конкурентоспроможного фахівця, але й створення умов для формування вмінь самоаналізу власної діяльності та готовності до самоаналізу, самоосвіти й самовдосконалення впродовж життя з метою реалізації усіх професійних здібностей, можливостей і резервів особистості. Оволодіння майбутнім викладачем методичною компетентністю (далі МК) неодмінно пов'язане з процесами осмислення, усвідомлення, формування особистісного ставлення до професії. Тому важлива роль у професійно-методичній підготовці майбутнього викладача IM належить формуванню його здатності до усвідомлення процесу оволодіння МК на різних етапах навчання у вищій школі, до аналізу власних методичних дій, індивідуального стилю учіння й методичної діяльності, способів самоорганізації, самооцінки, самокорекції, що передбачає рефлексивну діяльність магістрантів. У зв’язку з цим доцільно розглядати рефлексивний підхід як один із засадничих для організації освітнього процесу 3 формування МК магістрантів - майбутніх викладачів IM - під час їхньої самостійної роботи.

Мета статті - окреслити особливості реалізації рефлексивного підходу до формування МК у майбутніх викладачів IM у процесі їхньої самостійної роботи.

Компоненти рефлексивного підходу й особливості їх формування й розвитку під час оволодіння МК майбутніми викладачами ІМ. Під реалізацієюю рефлексивного підходу розуміємо таку організацію процесу самостійного оволодіння магістрантами МК, яка уможливлює формування й розвиток у них рефлексивного знання, рефлексивного мислення, рефлексивної позиції, рефлексивних умінь та методичної рефлексії з метою самоаналізу власної діяльності в процесі учіння та їі результатів під час педагогічної практики.

Рефлексивне знання, вважає О. М. Соловова, здатне з'єднати розрив між знанням як таким та його застосуванням, оскільки той, хто навчається, отримує його із аналізу як практичних, так і мисленнєвих дій; воно розглядається у площині бачення, розуміння, комплексного осмислення проблеми або ситуації, а також у площині організації індивідуальної та колективної діяльності в їі рамках (Соловова Е. Н., 2004, с. 99). 3 позицій формування МК йдеться про усвідомлене набуття магістрантами методичних знань упродовж самостійного оволодіння МК й аналіз, прогнозування можливостей їх реального практичного застосування, зокрема, в процесі професійно-методичної діяльності під час педагогічної практики.

Формування і розвиток рефлексивного мислення передбачає критичний аналіз магістрантом реалі- зації індивідуальної траєкторії учіння, поставлених цілей та обраного способу їх досягнення; розмірковування над ефективністю учіння, самоконтроль та критичну оцінку результатів, у разі необхідності прийняття рішення про корекцією індивідуальної траєкторії учіння тощо. Вважають, що рефлексивне мислення тісно пов'язане з активізацією рефлексивної позиції майбутнього фахівця, адже особистість 3 активною рефлексивною позицією постійно контролює й осмислює свою діяльність, усвідомлює способи досягнення цілей і визначає способи подолання перешкод на цьому шляху, коригує свою діяльність для оптимізації й максимально ефективної реалізації своїх цілей (Осипова Т. П., 2012, с. 163-164). Уточнимо й інтерпретуємо запропоновані авторкою етапи формування рефлексивної позиції в контексті формування МК: 1) усвідомлення магістрантом необхідності здійснення рефлексії в процесі учіння та під час майбутньої професійно-методичної діяльності; 2) самоаналіз індивідуально-психологічних особливостей, особливостей засвоєння навчального матеріалу для коректного вибудовування індивідуальної траєкторії учіння; 3) реалізація індивідуальної траєкторії учіння з метою оволодіння МК, аналіз отриманих результатів, самокорекція, визначення нових завдань; 4) творче використання рефлексії як засобу професійно-методичного розвитку та саморозвитку. Важливим є переосмислення методичних знань і вмінь, сформованих у процесі навчання (рівень вищої освіти «бакалавр»), опора на попередній методичний досвід й урахування його позитивних аспектів і труднощів для ефективного оволодіння МК в умовах магістратури.

Н. Ф. Коряковцева (Коряковцева Н. Ф., 2002, с. 13) акцентує позицію рефлексивної самооцінки, що означає здатність до рефлексивної самооцінки цілей, процесу і продукту діяльності учіння (у нашому випадку - опрацювання запропонованих викладачем навчальних матеріалів), рефлексію, корекцію і накопичення ефективного досвіду діяльності учіння, формування індивідуального стилю діяльності учіння (у нашому випадку - в процесі реалізації індивідуальної траєкторії учіння), перенесення раціонального досвіду у нові контексти (наприклад, у професійно-методичну діяльність під час педагогічної практики).

Безумовним атрибутом будь-якої особистіснозначущої діяльності, зазначає А. В. Хуторской, є здатність до саморегуляції та рефлексії (Хуторской А. В., 2006). Рефлексія - важлива професійна якість особистості викладача (Азимов Э. Г., 2009, с. 248), що визначається здатністю до ефективних рефлексивних процесів і високої рефлексивної самоорганізації (Пеняева С. А., 2008, с. 12). Дослідники зазначають, що саме під час рефлексії людина формує та розвиває свої цілі діяльності, спілкування й інших видів активності (Брушлинский А. В., 2003), а завдяки рефлексії самосвідомість є «живим» інструментом самоорганізації студента, сприяє фор- 
муванню вміння самонавчатися та самоконтролювати виконання власних дій (Коваль Т. І., 2007, с. 35). Рефлексія є засобом самоорганізації, оскільки якість підготовки фахівця, зазвичай, визначається не обсягом засвоєного ним змісту навчання, а вмінням самонавчання, самоконтролю та самоаналізу результатів діяльності і повинна відбуватися на всіх етапах навчання (Надточева Е. С., 2010; Фрицко Ж. С., 2006).

Здатність до рефлексії визначається рівнем сформованості рефлексивних умінь (Артюшина Л. А., 2008 , с. 3). Оволодіння магістрантом рефлексивними вміннями, з одного боку, дозволяє йому усвідомлювати, розуміти, аналізувати професійно-методичну діяльність, а з іншого - ефективно використовувати засоби регуляції цієї діяльності. Двосторонній процес рефлексії необхідний для викладача, щоб виступати в якості справжнього суб'єкта педагогічної діяльності (Ушева Т. Ф., 2010, с. 3).

У контексті формування МК майбутніх викладачів IM передбачається розвиток рефлексивних умінь: 1) здійснювати ретроспективний самоаналіз попереднього досвіду учіння у вищій школі та педагогічної практики, зокрема негативного (рівень вищої освіти «бакалавр») для проектування індивідуальної траєкторії учіння; 2) визначати особистісні потреби й мотиви для оволодіння МК, способи й стратегії реалізації індивідуальної траєкторії учіння; 3) визначати й усвідомлювати чинники, що впливають на ефективність учіння, коригувати індивідуальну траєкторію; 4) вибудовувати індивідуальний стиль учіння; 5) усвідомлювати власні помилки й прогалини в оволодінні МК та планувати учіння щодо їх подолання; 6) оцінювати рівень розвитку власної МК і планувати діяльність щодо їі вдосконалення. Саме вміння самоконтролю й рефлексії дозволяють самостійно коригувати учіння за визначеною індивідуальною траєкторією (Сысоев П. В., 2013, с. 130). Поділяємо точку зору Т. Ф. Ушевої у тому, що успішність оволодіння студентами рефлексивними вміннями детермінується реалізацією низки педагогічних умов (Ушева Т. Ф., 2010, с. 9). Окреслимо педагогічні умови, які забезпечують формування рефлексивних умінь у процесі формування МК у самостійній роботі майбутніх викладачів IM:

1. Діяльність учіння магістрантів за індивідуальною траєкторією в інформаційно-комунікаційному навчальному середовищі (далі ІКНС) (штучно створені викладачем умови в системі управління навчанням Moodle для асинхронної професійно орієнтованої самостійної навчально-пізнавальної й науково-дослідницької діяльностей за індивідуальною траєкторією учіння з використанням засобів навчання і контролю, комунікації й керування навчальним процесом). Навчаючись за індивідуальною траєкторією, магістрант може самостійно обирати з яким модулем / підмодулем працювати (при цьому виконання / невиконання попереднього за- вдання не впливає на можливість виконання наступного); розпочинати роботу 3 контентом модуля / підмодуля і завершувати їі у будь-який час і у будь-якій послідовності. Тому оволодіння магістрантами методичними знаннями і вміннями відповідно до власних індивідуально-психологічних особливостей і стилю навчання, самоконтроль за процесом і результатом учіння, постійна рефлексивна діяльність уможливлюють самостійне коригування обраної індивідуальної траєкторії учіння.

2. Організація навчального діалогу в процесі оволодіння методичними знаннями і вміннями забезпечується шляхом використання дидактичних можливостей і засобів діяльності Moodle й передбачає високий рівень інтерактивності, що реалізується шляхом суб'єкт-об'єктного зворотного зв'язку і встановлення суб'єкт-суб'єктних відносин у навчальній взаємодії суб'єктів освітнього процесу викладача з магістрантами і магістрантів між собою (наприклад, шляхом використання діяльностей «форум» (у розробленому автором статті IКНС форум «Методика навчання французької мови у вищій школі: обмін досвідом, навчальними матеріалами, обговорення проблем») і «чат» (в ІКНС пропонується така його тема: «Методика навчання французької мови у вищій школі: запитання і відповіді») для проведення консультацій.

3. Квазіпрофесійна діяльність. У процесі методичної підготовки магістранта імітуються (моделюються) типові ситуації професійно-методичної діяльності викладача, вирішення яких відбувається шляхом виконання навчально-методичних задач 3 метою оволодіння методичними вміннями на основі набутих методичних знань. Квазіпрофесійну діяльність магістранти здійснюють постійно в процесі виконання навчально-методичних задач (засіб навчально-пізнавальної діяльності магістрантів 3 оволодіння методичними вміннями й контролю за рівнем їх сформованості в межах усіх компетенцій і субкомпетенцій, які складають МК майбутнього викладача IM) в IКНС (наприклад, аналізуючи i трансформуючи вправи, аналізуючи й розробляючи самостійно електронні засоби навчального призначення, добираючи навчальний матеріали для різних цілей) та під час семінарських занять з методики навчання IM у вищій школі. Наприклад, творча навчально-методична задача на розроблення плану-конспекту окремого фрагменту практичного заняття з IM передбачає його презентацію на семінарському занятті у формі професійно орієнтованої рольової гри, де магістрант-розробник плану конспекту, виступаючи у ролі викладача, реалізовує його зі своїми одногрупниками, які виконують ролі студентів відповідного етапу навчання.

4. Навчання аналізу методичних ситуацій з різних позицій відбувається як у процесі виконання навчально-методичних задач в ІКНС, так і під час професійно орієнтованої рольової гри, де, виконуючи роль викладача, магістрант має можливість 
апробувати розроблені навчально-методичні матеріали, здійснити самоаналіз щодо ефективності розробленого фрагменту практичного заняття, методичної доцільності обраних прийомів навчання, своєї мовленнєвої поведінки тощо; отримати рекомендації викладача та інших членів академічної групи щодо коректності сформульованих цілей, обраних способів їх реалізації, методичної доцільності використовуваних засобів навчання, режимів роботи тощо в процесі обговорення проведеного фрагменту практичного заняття. Отже, у ситуації безпосередньої взаємодії зі «своїми» студентами, а також на етапі самоаналізу і самооцінки власної діяльності впродовж професійно-рольової гри й оцінки викладачем та іншими магістрантами, формується «здатність прогнозувати й адекватно оцінювати як «ідеальні», так і реальні свої результати своїх дій» (Бессонова Е. А., 2000, с. 27).

Рефлексивні вміння магістранта формуються під час самостійної роботи в ІКНС й розвиваються впродовж педагогічної практики на різних етапах його діяльності як викладача IM.

Аналіз наукових доробку і власний педагогічний досвід доводить, що методична рефлексія пронизує всі види професійно-методичної діяльності викладача IM, тому їі роль у формуванні МК магістрантів важко переоцінити. 3 точки зору організації освітнього процесу методична рефлексія - це самоаналіз власної діяльності безпосередньо в процесі учіння, а у професійно-методичній діяльності викладача вона передбачає самоаналіз ефективності проектування,конструювання,реалізації,прогнозування навчально-виховного процесу (Краевский В. В., Бережнова Е. В., 2006). Тому, якщо йдеться про педагогічний процес, методична рефлексія є одним із найважливіших предметів навчання і засвоєння, те найвище, розвиток якого і є метою професійної підготовки (Генисаретский О. И., 1970) та системотворчим компонентом освіти впродовж життя (Князян М. О., 2006). Відтак, методична рефлексія учіння магістрантів в процесі оволодіння МК реалізується у двох аспектах: 1) у процесі опрацювання запропонованих викладачем навчальних матеріалів для формування МК у самостійній роботі в ІКНС, де об'єктами методичної рефлексії є ступінь оволодіння методичними знаннями й уміннями під час виконання завдань і навчально-методичних задач; 2) у реальних умовах освітнього процесу з під час педагогічної практики з IM, де об'єктами методичної рефлексії виступають методичні дії магістранта, ї доцільність, результативність, успішність, способи і прийоми професійно-методичної діяльності, які мали позитивний ефективний результат, труднощі та їх причини, комунікативна поведінка, прийоми організації соціальної взаємодії, методичні помилки.

Рефлексія - це якість, яка розвивається, і найінтенсивніше їі розвиток відбувається в спеціально організованій інноваційній діяльності (Гуреев А. П., 2001), а розвиток методичної рефлексії передбачає використання різних методів (наприклад, спостереження за методичними діями викладача та магістрантів під час педагогічної практики, стратегіями комунікативної поведінки на практичному занятті, їх аналіз; аналіз практичного заняття / позааудиторного заходу в цілому чи окремих фрагментів), прийомів і засобів.

На етапі розроблення плану-конспекту практичного заняття, проектування навчальної діяльності студентів (визначення цілей, вибір засобів і прийомів навчання з урахуванням індивідуально-психологічних особливостей студентів тощо) ефективним прийомом розвитку методичної рефлексії є самоаналіз розробленого плану-конспекту за запропонованою викладачем схемою, яка представлена в ІКНС. Наведемо $\dddot{1}$ приклад.

\section{Шановний магістранте!}

Ви завершили розроблення плану-конспекту практичного заняття. Пропоную Вам перевірити чи визначили Ви тип і вид практичного заняття;чи сформулювали цілі практичного заняття: практичну, лінгвосоціокультурну, розвивальну, виховну, професійну; чи конкретизували обладнання, яке буде використано на практичному занятті; чи уклали схематичний план практичного заняття $i$ адекватно розподілили час; чи до кожного етапу практичного заняття визначили прийоми навчання; чи оптимальними є заплановані режими роботи; чи дiбрали / розробили засоби навчання; чи передбачили вправи і завдання для реалізацї професійного компоненту (професійної мети); чи спланували початок $i$ завершення (підсумки, рефлексія) практичного заняття; чи дотрималися логіки побудови практичного заняття (зв'язок фонетичної / мовленнєвої зарядки з наступними етапами практичного заняття, взаємозв'язок кожного етапу практичного заняття 3 попереднім і наступним тощо).

Відповіді на иі запитання дозволять Вам здійснити аналіз розробленого плану-конспекту і внести відповідні корективи, що, сподіваюсь, додасть Вам впевненості під час проведення практичного заняття.

Реалізується розроблений план-конспект на практичному занятті з іноземної мови під час педагогічної практики, де магістранти в реальних умовах організації освітнього процесу виконують роль викладача у відповідній академічній групі. На цьому етапі майбутній викладач здійснює методичну рефлексію запланованого і реального результатів організації практичного заняття з IM за запропонованою викладачем схемою. Це спонукає його до пошуку альтернативних способів вирішення методичних задач і проблем, свідомої вмотивованості й обгрунтованого планування методичних дій, формування ціннісного ставлення до майбутньої професійно-методичної діяльності, розвитку професійно особистісних якостей, «створює пере- 
думови для реалізації креативних й інноваційних підходів до власної діяльності» (Сухих О. В., 2009). Наведемо приклад схеми самоаналізу проведеного практичного заняття, яку представлено в ІКНС.

\section{Шановні магістранти!}

Після кожного проведеного Вами практичного заняття рекомендую здійснювати його самоаналіз за запропонованою нижче схемою. У такий спосіб ви зможете виявити свої «сильні» $i$ «слабкі» сторони, що дозволить вам поступово підвищити ефективність професійно-методичної діяльності як майбутнього викладача IM.

1. Цілі практичного заняття досягнуто повністю / не досягнуто тому, що...

2. Протягом практичного заняття студенти набули знань / поглибили знання про .../ оволоділи навичками ... / оволоділи вміннями ...

3. Час на практичному заняття використано раціонально / нераціонально з таких причин: ...

4. Протягом практичного заняття вносилися такі корективи у розроблений планконспект: .......... через те, що ...

5. На цьому практичному занятті мені особливо вдалося ...

6. Основними недоліками практичного заняття я вважаю ...

Причини цих недоліків:...

7. Якби я проводив / проводила це практичне заняття ще раз, то я б вніс / внесла такі корективи у структуру практичного заняття:... / у зміст практичного заняття: ... / в організачію практичного заняття: ...

Ефективним засобом розвитку методичної рефлексії вважаємо електронний методичний портфель майбутнього викладача IM як постійну електронну фіксацію магістрантом своїх методич- них досягнень. Електронний методичний портфель формується в процесі навчання з метою оцінювання власного прогресу й накопиченого досвіду під час оволодіння МК у вищій школі (у ньому магістрант може зберігати самостійно виконані навчальнометодичні задачі, залишені викладачем коментарі й рекомендації у процесі їх перевірки; дібрані / розроблені засоби навчання, дібрані Інтернетресурси навчального призначення, самостійно розроблені електронні засоби навчального призначення; дидактичні матеріали до магістерської роботи тощо, які можуть бути корисними як під час педагогічної практики, так і в майбутній професійній діяльності). Розроблення методичного портфеля на основі інформаційно-комунікаційних технологій дозволяє забезпечити оперативний доступ до його контенту, зберігати його матеріали в різних форматах, оперативно оновлювати й редагувати їх, вносити корективи й використовувати, зокрема й у режимі реального часу на семінарських заняттях $з$ навчальної дисципліни «Методика навчання IM у вищій школі» або під час педагогічної практики.

Висновки. Результатом формування МК на засадах рефлексивного підходу має стати професійнометодичний розвиток і особистісні трансформації майбутніх викладачів IM, сформована готовність до постійного рефлексивної діяльності, інтерпретації власних методичних досягнень на особистісному рівні, що впродовж життя сприятиме формуванню власних рефлексивних стратегій і слугуватиме підгрунтям для підвищення майстерності викладача.

Перспективи подальших наукових розвідок вбачаємо в обгрунтуванні й розробленні комплексів завдань для формування й розвитку методичної рефлексії в процесі професійно-методичної підготовки майбутніх викладачів IM.

\section{Література}

1. Азимов Э. Г. Новый словарь методических терминов и понятий (теория и практика обучения языкам) / Э. Г. Азимов, А. Н. Щукин - М. : Издательство ИКАР, 2009. - 448 с.

2. Артюшина Л. А. Дидактические средства включения рефлексивных умений школьников в содержании образования : автореф. дис. на соискание учен. степени канд. пед. наук: спец. 13.00.01 «Общая педагогика, история педагогики и образования» / Л. А. Артюшина. - Нижний Новгород, 2008. - 24 с.

3. Бессонова Е. А. Рефлексия и её развитие в процессе учебно-профессионального становления будущего учителя: дис. ... канд. психол. наук : 19.00.07 / Бессонова Елена Анатольевна. - Хабаровск, 2000. - 160 с.

4. Брушлинский А. В. Субъект : мышление, учение, воображение : Избранные психологические труды. - [2-е изд., испр.] / А. В. Брушлинский. - М. : Издательство Московского психолого-социального института; Воронеж : Издательство НПР «МОДЭК», 2003. - 408 с.

5. Генисаретский О. И. Понятие о методической рефлексии и методических коммуникациях [Електронний ресурс] / О. И. Генисаретский. - Режим доступу: http://prometa.ru/olegen/publications/17

6. Гуреев А. П. Рефлексия профессиональной деятельности педагога как психолого-педагогическая проблема : дис. ... канд. пед.. наук: 13.00.01, 13.00.08. - Челябинск, 2001. - 154 с.

7. Князян М. О. Самостійно-дослідницька діяльність майбутніх учителів іноземних мов: теорія і практика: монографія / Марія Олексіївна Князян. - Ізмаїл : Сміл, 2006. - 242 с.

8. Коваль Т. І. Професійна підготовка з інформаційних технологій майбутніх менеджерів-економістів : монографія / Тамара Іванівна Коваль. - К. : Ленвіт, 2007. - 264 с.

9. Коряковцева Н. Ф. Современная методика организации самостоятельной работы изучающих иностранный язык : [пособие для учителей] / Наталия Федоровна Коряковцева. - М. : АРКТИ, 2002. - 176 с. 
10. Краевский В. В. Методология педагогики: новый этап: [учеб. пособие для студ. высш. учеб. заведений] / В. В. Краевский, Е. В. Бережнова. - М. : Издательский центр «Академия», 2006. - 400 с.

11. Майєр Н. В. Теоретико-методичні засади формування методичної компетентності у майбутніх викладачів французької мови : дис. ... доктора пед. наук : 13.00.02 / Майєр Наталія Василівна. - К., 2016. - 735 с.

12. Надточева Е. С. Развитие профессионально-методической компетенции будущего учителя иностранного языка / Е. С. Надточева // Известия Уральского государственного университета. Сер. 1. Проблемы образования, науки и культуры. - 2010. - N 3 (78). - С. 103-109.

13. Осипова Т. П. Рефлексивно-деятельностный подход в процессе профессиональной подготовки студентов / Т. П. Осипова // Ярославский педагогический вестник. - 2012. - № 1. - Том II. (Психолого-педагогические науки). - С. 163-166.

14. Пеняева С. А. Рефлексивные составляющие компетентности и особенности их формирования у студентов в процессе обучения / С. А. Пеняева // Стандарты и мониторинг в образовании. - 2008. - № 1 (январь-февраль). - С. 11-14.

15. Соловова Е. Н. Методическая подготовка и переподготовка учителя иностранного языка : интегративно-рефлексивный подход : монография / Елена Николаевна Соловова. - М.: Издательство Глосса-пресс, 2004. - 336 с.

16. Сухих О.В. Принципы лингводидактической подготовки преподавателя иностранных языков и культур : [Електронний ресурс] / О. В. Сухих. - Режим доступу: http://pglu.ru/upload/iblock/2cf/ uch_2009_viii_00007.pdf

17. Сысоев П. В. Обучение по индивидуальной траектории / П. В. Сысоев // Язык и культура. 2013. - № 4(24). - C. 121-131.

18. Ушева Т.Ф. Педагогические условия формирования рефлексивних умений студентов в учебном процессе вуза: автореф. дис. на соискание уч. степени канд. пед. наук : спец. 13.00.01 - общая педагогика, история педагогики и образования / Т. Ф. Ушева. - Новокузнецк, 2010. - 24 с.

19. Фрицко Ж. С. Проектная деятельность студентов педагогического колледжа при обучении иностранному языку как средство формирования методических умений : дис. ...канд. пед. наук : 13.00 .08 / Фрицко Жанна Сергеевна. - Екатеринбург, 2006. - 208 с.

20. Хуторской А. В. Проблемы и технологии образовательного целеполагания : [Електронний ресурс] / А. В. Хуторской. - Режим доступу: http: // www.eidos.ru/journal/2006/0822-1.htm

21. Щербина О. А. Швидке створення облікових записів студентів та їх реєстрація в курсах платформи Moodle 2 / О. А. Щербина // Інформаційні технології в освіті: Збірник наукових праць, № 23. - Херсон. Вид. Херсонськ. держ. унів-ту, 2015. - С. 79-89, DOI: 10.14308/ite000538.

\title{
РЕФЛЕКСИВНЫЙ ПОДХОД К ФОРМИРОВАНИЮ МЕТОДИЧЕСКОЙ КОМПЕТЕНТНОСТИ У БУДУЩИХ ПРЕПОДАВАТЕЛЕЙ ИНОСТРАННЫХ ЯЗЫКОВ В ПРОЦЕССЕ САМОСТОЯТЕЛЬНОЙ РАБОТЫ
}

Майер Наталия, доктор педагогических наук, доцент, Киевский национальный лингвистический университет, ул. Большая Васильковская, д. 73, 03680 г. Киев, Украина, teacher123@ukr.net

В статье рассмотрен рефлексивный поход как один из основополагающих для организации ученого процесса с иелью формирования методической компетентности будущих преподавателей иностранных языков в самостоятельной работе. Описаны особенности реализации рефлексивного подхода путём соответствующей организации образовательного процесса, направленного на формирование и развитие у магистрантов рефлексивного знания, рефлексивного мышления, рефлексивной позиции, рефлексивных умений, методической рефлексии.

Ключевые слова: будущий преподаватель иностранных языков; информационно-коммункационная обучаюшая среда; магистрант; методическая компетентность; методическая рефлексия; рефлексивный подход; самостоятельная работа.

\section{THE REFLEXIVE APPROACH TO THE FORMATION OF METHODICAL COMPETENCE OF FUTURE TEACHERS OF FOREING LANGUAGES IN THE PROCESS OF SELF STUDY}

\author{
Mayer Natalia, Doctor of Pedagogical Science, senior lecturer, Kyiv National Linguistic University, \\ 73 Vasylkovska Str., 03680 Kyiv, Ukraine, teacher123@ukr.net
}

The article describes a reflective campaign as one of the fundamental for the organization of academic process to the formation of methodical competence of the future teachers of foreign languages in independent work. The features of realization of reflexive approach by the relevant organization of the educational process aimed at the formation 
and development in the graduate, the future teachers of foreign languages, reflective knowledge, reflective thinking, reflexive position, reflective skills, methodological reflection. It is proved that methodological reflection in the process of mastering the methodological competence is realized in two ways: while the undergraduates with the proposed teacher training materials in information and communication and learning environment under actual conditions of the educational process in pedagogical practice. As a result of formation of methodical competence, taking into account the basic provisions of the reflexive approach should be professional and methodological development and personal transformation of the future teachers of foreign languages, formed readiness for constant reflexive activity, the interpretation of its own methodological advances on a personal level, that during the life will contribute to the formation of its own reflexive strategies and It will serve as a basis for improving teacher skills. The prospect of further research in this direction could be a theoretical basis and practical development of complex tasks for the formation and development of methodological reflection in the process of professional and methodical preparation of the future teachers of foreign languages.

Keywords: future teacher of foreign languages; independent work; information and communication training environment; methodical competence; methodological reflection; reflective approach; undergraduate.

Стаття надійшла до редакції 02.09.2016

Прийнято до друку 27.10.2016

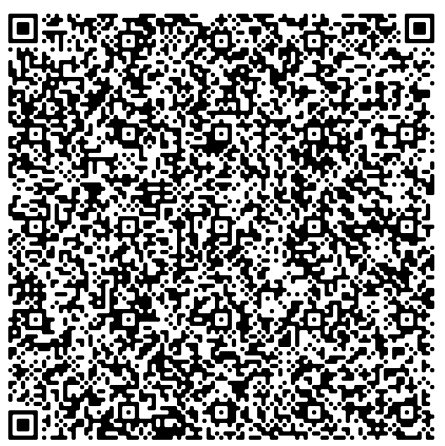

УДК 37.0:37.013

Наталія Ржевська

ORCID iD 0000-0001-8695-5964

здобувач наукового ступеню, ДВНЗ «Переяслав-Хмельницький державний педагогічний університет ім. Г. Сковороди» вул. Сухомлинського, 30, 08401 м. Переяслав-Хмельницький, Україна; методист навчального відділу, Київський національний торговельно-економічний університет вул. Кіото, 19, 02156 м. Київ, Україна zolotysya@ukr.net

\section{ОСНОВИ ПРАВОВОЇ КОМПЕТЕНТНОСТІ БАКАЛАВРА 3 ПІДПРИЕМНИЦТВА, ТОРГІВЛІ ТА БІРЖОВОЇ ДІЯЛЬНОСТІ}

Автором зроблено спробу дослідити пакет актуальних компетентностей бакалавра з підприємництва, торгівлі та біржової діяльності. У статті наголошується на неможливості визначення сталої сукупності компетентностей, адженові реалї економічної фери вносять корективи до функціональнихобов'язків фахівия. Автором проаналізовано та узагальнено перелік компетентностей зазначеного фахівия, що визначені в профілях освітніх програм зазначеної спеціальності вищих навчальних закладів України. Досліджені та обгрунтовані правові основи для певних компетентностей. Автором досліджено основи правової компетентності бакалавра з підприємництва, торгівлі та біржової діяльності, що уособлюють в собі поняття правової культури, правового менталітету, правової свідомості, правової поведінки.

Ключові слова: бакалавр з підприємництва, торгівлі та біржової діяльності; компетентність; правова культура; правова поведінка; правова свідомість; правовий менталітет.

Вступ. В умовах включення України до європейської міжнародної політики на перший план виступає співставлення знань та стандартів якості українського та європейського простору, конкурентоспроможність українських фахівців, актуальність і затребуваність їхніх компетентностей суб'єктами міжнародної політики. В умовах інноваційного розвитку підприємництва, посилення торговельних оборотів, інтеграції України у світовий біржовий ринок змінилися вимоги роботодавців до якості підготовки майбутніх випускників, розширилася сфера їх професійної діяльності. Описані аспекти обумовлюють нагальну потребу у дослідженні актуальних компетентностей бакалавра з підприємництва, торгівлі та біржової діяльності.

Мета статті - узагальнити перелік актуальних компетентностей бакалавра з підприємництва, торгівлі та біржової діяльності, що заявлені у профілях програм провідних вищих навчальних закладів України. За допомогою аналізу визначити роль правової компетентності для формування інших компетентностей бакалавра зазначеної спеціальності. 